\title{
Archaeological Testing at Goliad State Park, Goliad County, Texas
}

Johanna M. Hunziker

Center for Archaeological Research

Anne A. Fox

Center for Archaeological Research

Follow this and additional works at: https://scholarworks.sfasu.edu/ita

Part of the American Material Culture Commons, Archaeological Anthropology Commons, Environmental Studies Commons, Other American Studies Commons, Other Arts and Humanities Commons, Other History of Art, Architecture, and Archaeology Commons, and the United States History Commons

Tell us how this article helped you.

This Article is brought to you for free and open access by the Center for Regional Heritage Research at SFA ScholarWorks. It has been accepted for inclusion in Index of Texas Archaeology: Open Access Gray Literature from the Lone Star State by an authorized editor of SFA ScholarWorks. For more information, please contact cdsscholarworks@sfasu.edu. 


\section{Archaeological Testing at Goliad State Park, Goliad County, Texas}

Creative Commons License

(c) (i) (8)

This work is licensed under a Creative Commons Attribution-NonCommercial 4.0 International License 


\section{Archaeological Testing at Goliad State Park, Goliad County, Texas}

Johanna M. Hunziker and Anne A. Fox

Robert J. Hard and C. Britt Bousman

Principal Investigators

${ }^{\circ}$ copyright

Center for Archaeological Research The University of Texas at San Antonio Archaeological Survey Report, No. 260 
The following information is provided in accordance with the General Rules of Practice and Procedure, Chapter 41.11 (Investigative Reports), Texas Antiquities Committee:

1. Type of investigation: Testing

2. Project name: Goliad State Park

3. County: Goliad

4. Principal investigator: Robert J. Hard

5. Name and location of sponsoring agency: Texas Parks and Wildlife Department, 4200 Smith School Road, Austin, Texas 78744

6. Texas Antiquities Committee Permit No: TPWD Annual Permit No. 1778

7. Published by the Center for Archaeological Research, The University of Texas at San Antonio, $6900 \mathrm{~N}$. Loop 1604 W., San Antonio, Texas 78249-0658, 1998

A list of publications offered by the Center for Archaeological Research is available. Call (210) 458-4378; write to the Center for Archaeological Research, The University of Texas at San Antonio, 6900 N. Loop 1604 W., San Antonio, Texas 78249-0658; e-mail to car@lonestar.utsa.edu; or visit CAR's Web site at http://www.csbs.utsa.edu/research/car/index.htm. 


\begin{abstract}
In December 1996, the Center for Archaeological Research (CAR) of The University of Texas at San Antonio entered into a contract with the Texas Parks and Wildlife Department to conduct archaeological investigations at Mission Espiritu Santo in Goliad State Park. On December 17, 1996, a seven-member field crew from CAR excavated 32 shovel tests along the proposed trench for replacement of existing park water and electrical lines between the mission compound and the camping area. Artifacts recovered from the shovel tests include Spanish colonial ceramics, glass, metal, stone tools and debitage, and a large quantity of animal bone. Most of the artifacts were recovered from the shovel test pits near the mission wall. Any new trenching in this area would disturb possible intact Colonial deposits. Very few artifacts were recovered from the remainder of the proposed trench line.
\end{abstract}




\section{Contents}

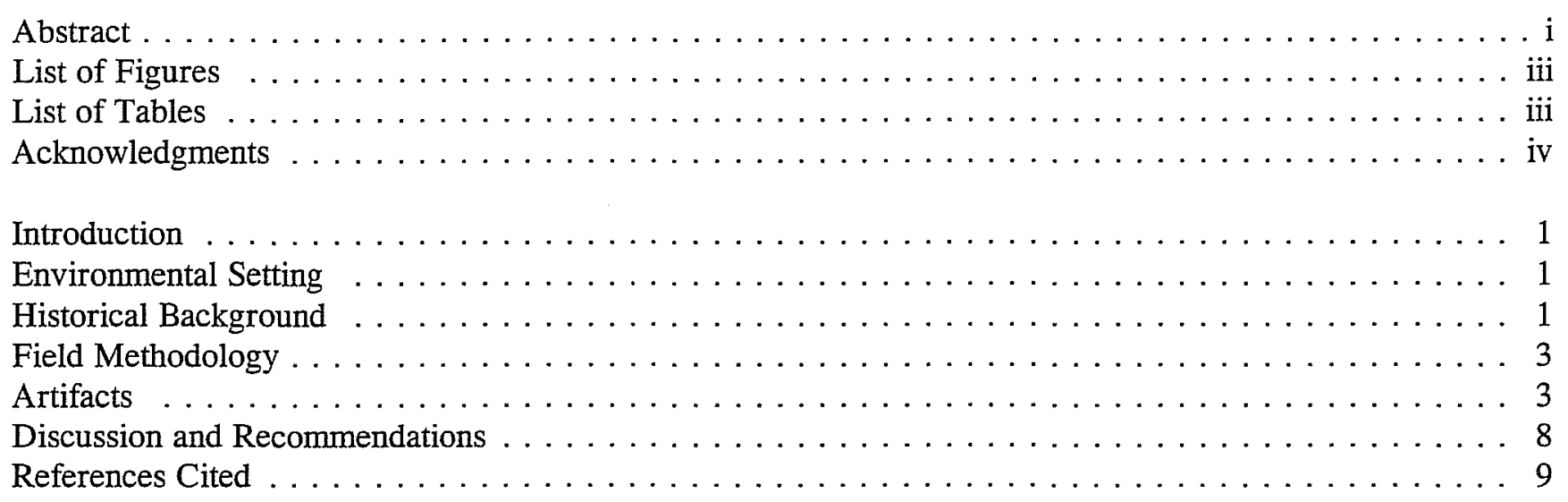




\section{Figures}

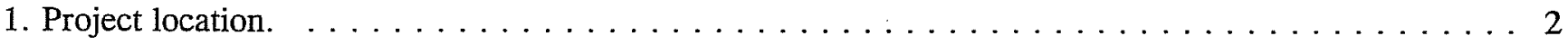

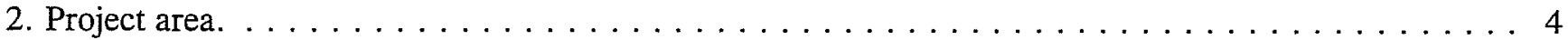

\section{Tables}

1. Ceramics Recovered from Shovel Tests $\ldots \ldots \ldots \ldots \ldots \ldots \ldots \ldots \ldots \ldots$

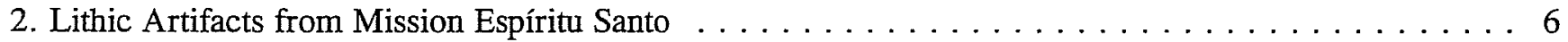

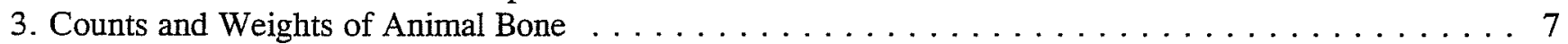




\section{Acknowledgments}

The authors wish to acknowledge Art Black and George Krezinski of the Texas Parks and Wildlife Department for their help in coordinating this project. The timely completion of the fieldwork was due to the efforts of the following CAR staff: John Arnn, Owen Ford, Kevin Gross, Ed Johnson, Andrew Scease, and the project director Cynthia Tennis. Thanks also go to Marcie Renner for editing this report, and to Bruce Moses for drafting the figures. 


\section{Introduction}

Pursuant to a contract between the Texas Parks and Wildlife Department and the Center for Archaeological Research (CAR) of The University of Texas at San Antonio under an interagency agreement, a cultural resource study was undertaken at Mission Espíritu Santo at Goliad State Park. The project area is located within the portion of the park which contains the mission complex, the park headquarters and ranger's residence, and the camping area. The latter is a paved loop with 20 recreational vehicles spaces and five bungalows.

Archaeological investigations were conducted to assess the impact of the replacement of the existing water and electrical lines. The area tested extends approximately 800 linear meters, starting about $15 \mathrm{~m}$ outside the eastern mission wall and continuing southsouthwest to the camping area. Thirty-two shovel tests were excavated along the impact area by a seven-member crew on December 17, 1996.

\section{Environmental Setting}

The project area is located within Goliad State Park just south of the town of Goliad, in Goliad County, Texas. Mission Espiritu Santo is located within the park on a bend of the San Antonio River (Figure 1). The mission complex sits on the second terrace approximately $200 \mathrm{~m}$ due east of the river, at an elevation of $150 \mathrm{ft}(46 \mathrm{~m})$ above mean sea level (amsl). The camping area is situated on the lower terrace to the southwest of the mission at $130 \mathrm{ft}$ $(40 \mathrm{~m})$ amsl. Because of the bend in the river, the camping area is also approximately $200 \mathrm{~m}$ due east of the river.

Soils in the project area are shallow to moderately deep loamy surface layers with clayey subsoils (Godfrey et al. 1973). Indurated caliche occurs at varying depths throughout the area. The project area is situated near the southern boundary of the Texan Biotic Province and the northern edge of the Tamaulipan Biotic Province (Blair 1950). Vegetation is a mixture of the oak-hickory forests and tall-grass prairie of the Texan Province and the mesquite- thorny brush of the Tamaulipan Province (Map, The Vegetation Types of Texas, Texas Parks and Wildlife Department, Austin, Texas, 1984). Common species include post oak, blackjack oak, hickory, mesquite, black brush, Texas persimmon, huisache, prickly pear, and various grasses (Blair 1950).

\section{Historical Background}

Mission Espíritu Santo de Zuñiga was first founded in 1721 in conjunction with Presidio Nuestra Señora de Loreto de La Bahía on Garcitas Creek near Matagorda Bay (Ramsdell 1934:1). The presidio was located on the site of La Salle's ill-fated settlement on the east side of the creek; the original mission site has yet to be located. Due to crop failures and trouble between the Indians and the military, this mission's attempt was not successful, and by June 1726 it had been reestablished on the Guadalupe River. The presidio soon followed and the two were located in Mission Valley 10 miles north of present-day Victoria for the next 23 years. Here they ministered to the Aranama and Tamique Indians.

In 1749 the mission and presidio were moved again, this time to the San Antonio River to what is now the town of Goliad (Bolton 1970 [1915]:296). The friars continued to work with the Aranama Indians with great success. Mission Nuestra Señora del Rosario was founded four miles from Espíritu Santo on the opposite side of the river in 1755 , enlarging the settlement and bringing in coastal Indians.

By 1758 Mission Espíritu Santo consisted of a stone church, a convento, and thatched huts for the Indians. The mission had 3,200 head of cattle and 1,600 sheep by this time (Castañeda 1938:22-23). Twenty-eight years later, the mission, which was by this time surrounded by a stone wall, consisted of Indian houses with grass, straw, or dried-mud roofs, workshops, a granary, and a church with a sacristy (Mounger 1959:33). Its greatest source of revenue was cattle raising, and next to Mission San José at San Antonio, it was the most important cattle-raising mission in Texas. By 1779 Goliad, with a population of 695 , and San Antonio, population 2,060, were the only two population centers in central and south Texas. 

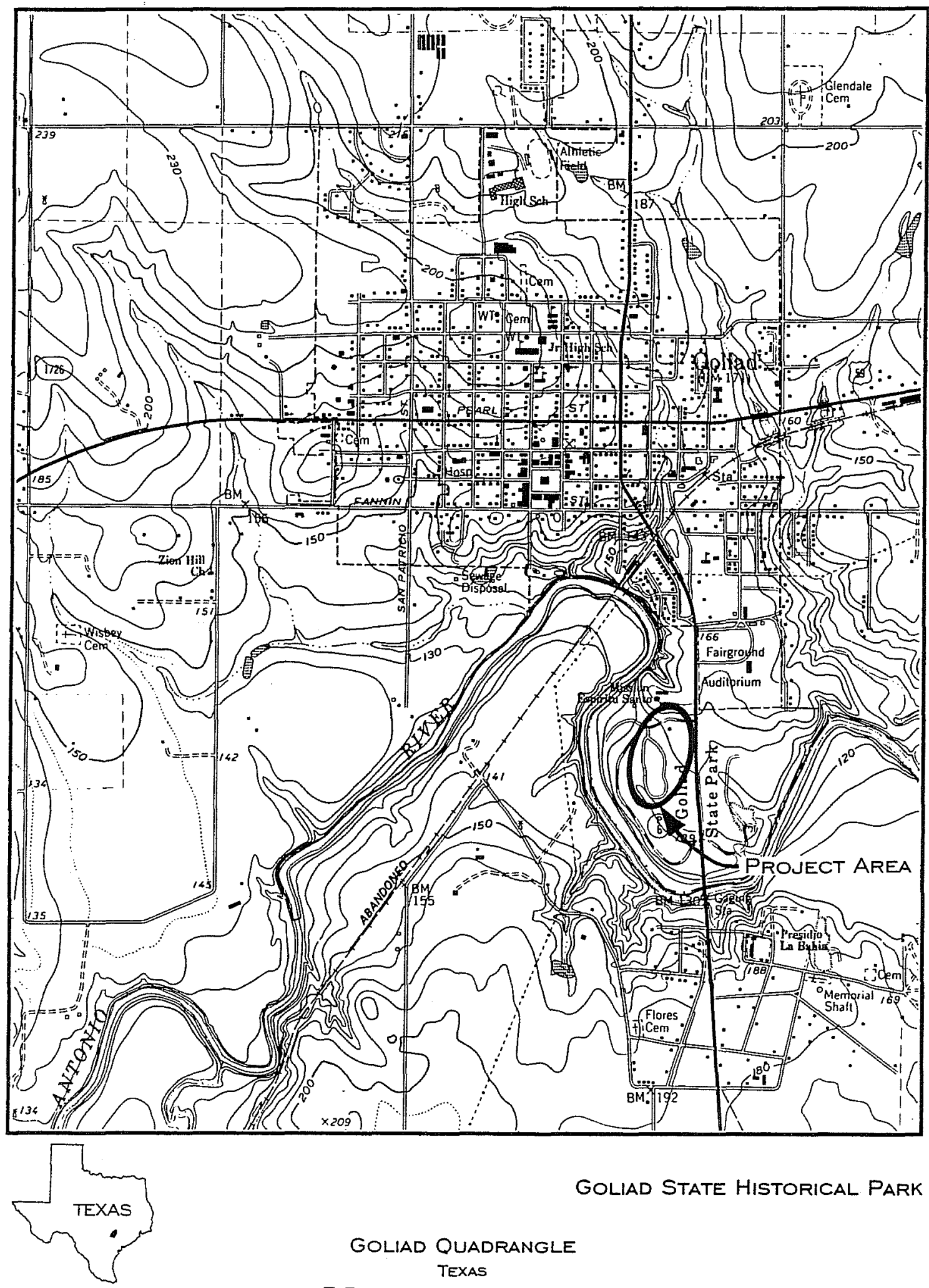

Goliad State Historical PARK

oUADRANGLE LOCATION

Goliad QuAdRANGLe

TEXAS

7.5 MINUTE SERIES (TOPOGRAPHIC)

Figure 1. Project location. 
From this point on, a gradual decline in cattle and Indian population occurred at the mission (Mounger 1959:37). By 1790 the buildings were deteriorating and some walls had collapsed. In 1794 the secularization of all the Texas missions had begun, and by 1817 only 48 Indians were still living at the mission (Mounger 1959:50).

Documents indicate that the battles of the Texas Revolution primarily involved the presidio and ignored the mission ruins. Additionally, a traveler's account of the area in 1850 mentions that a gentleman from New York was living in the old mission church at that time (Freidrichs 1967:60). The few remaining buildings and the 20 acres of mission lands were donated to the Presbyterian Church in 1852 to be used for a college. The college eventually built a large building on the mission grounds, the location of which is not presently known. This educational institution operated until the entire student body enlisted in the Confederate Army at the start of the Civil War. The school building was destroyed by a hurricane in 1886 (Roell 1996:215).

Ownership of the property eventually reverted to the city of Goliad, which donated it to the State Parks Board in the 1930s. The mission was reconstructed by the state in 1936 (O'Connor 1966:243). From that time to the present it has been administered as a historic and recreational park by the Texas Parks and Wildlife Department.

\section{Field Methodology}

The construction contractor marked the route of the existing water pipeline prior to the archaeological investigation. This route was used as the reference for placement of the shovel tests (Figure 2). The pipeline runs in a north-south direction outside the eastern wall of the mission down to the park manager's residence. At this point it turns and runs in a southwesterly direction until it intersects the campground (Figure 2). Within the campground, the proposed pipeline splits, with one section running along the outside of the paved road and the other along the inside.
In the area between the mission and the campground, shovel tests were placed at $15-\mathrm{m}$ intervals, one meter east of the existing pipeline. Within the campground, shovel tests were excavated at $30-\mathrm{m}$ intervals along the eastern side of the loop and were placed on the "islands" between the paved campsites along the southern and western portions of the loop. Shovel tests were $40 \mathrm{~cm}$ square and were excavated to a minimum depth of $50 \mathrm{~cm}$. Tests were extended to a maximum depth of $80 \mathrm{~cm}$ when artifacts were encountered. Shovel tests were excavated in $10-\mathrm{cm}$ levels, and soil was screened through $1 / 4$-inch wire mesh.

Thirty-two shovel tests were excavated: 13 at $15-\mathrm{m}$ intervals near the mission, and the remaining 19 at $30-\mathrm{m}$ intervals within the campsites. STs $1-5$ ran along the side of the mission wall and down the terrace slope to the park road. STs 6-9 were located near the park residence on a slight artificial rise on the lower terrace. STs 10-32 were located on the lower terrace west of the park residence and within the camping area (Figure 2).

\section{Artifacts}

Artifacts were recovered from 18 of the 32 shovel tests. Artifact types include unglazed brownwares, tin-glazed earthenwares, glass, nails, stone tools and flakes, animal bone, and mussel shell. In all, 1,557 artifacts were collected, 1,327 of which were animal bone.

A high concentration of artifacts, mostly animal bone, were recovered from STs 1,2, and 3. ST 3 appeared to be disturbed, as nineteenth-century artifacts were recovered from as deep as $60 \mathrm{~cm}$ below the surface. Very few artifacts were recovered from STs 4 and 5, and a solid calcium carbonate layer was encountered between 30 and $40 \mathrm{~cm}$ below surface in both tests. Very few and scattered artifacts were recovered from the shovel tests within the camping area. 


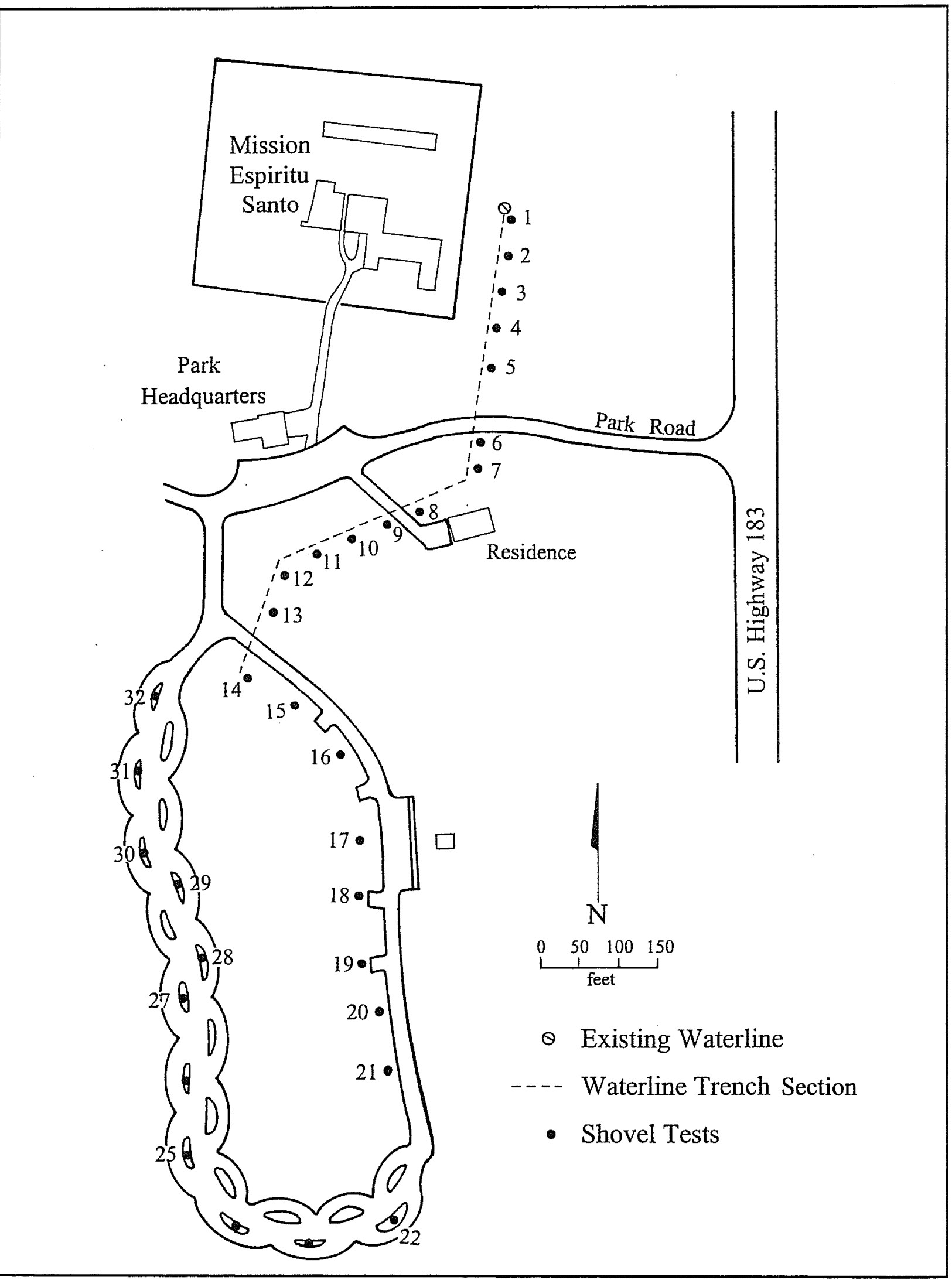

Figure 2. Project area. 


\section{Unglazed Wares}

Two varieties of unglazed brownwares were recovered: Goliad and Valero. Goliad wares are characterized by a course-grained paste with bone temper. The exterior is tan to reddish brown in color, while the interior usually contains dark organic streaks (Hard et al. 1995). Goliad ware is thought to be a continuation of the local Native American ceramic style (Ivey and Fox 1982). Valero wares are wheel made and have a pinkish-tan colored paste with fine sand or occasional bone temper (Hard et al. 1995). Valero wares were manufactured locally between 1730 and 1760 (Ivey and Fox 1982). Sixty-seven sherds of Goliad ware were recovered, 64 of which came from STs 1-3 (Table 1). Thirty-four (51 percent) of the
Goliad sherds were recovered from ST 1. All five pieces of Valero ware were recovered from ST 3.

\section{Glazed Wares}

Tin-glazed wares, or majolicas, have a decorated white opaque glaze and the paste ranges in color from cream to pink to red (Hard et al. 1995). These ceramics were exported from México to the Spanish frontier throughout the Spanish colonial period up until the early nineteenth century (Ivey and Fox 1982). Four tin-glazed sherds were recovered from STs 1, 2, and 3 (Table 1). Two of the sherds had white paste, the other two had red paste.

Table 1. Ceramics Recovered from Shovel Tests

\begin{tabular}{|c|c|c|c|c|c|}
\hline \multirow{2}{*}{ Unit } & \multirow{2}{*}{ Level } & \multicolumn{2}{|c|}{ Brownwares } & \multirow{2}{*}{ Tin-Glazed } & \multirow{2}{*}{ Notes } \\
\hline & & Goliad & Valero & & \\
\hline \multirow[t]{6}{*}{ ST 1} & 1 & 4 & & & Two rim sherds \\
\hline & 2 & 7 & & & \\
\hline & 3 & 7 & & 2 & Tin-glazed with white paste \\
\hline & 4 & 12 & & & \\
\hline & 5 & 2 & & & Two rim sherds \\
\hline & 7 & 2 & & & \\
\hline \multirow[t]{7}{*}{ ST 2} & 2 & 1 & & & \\
\hline & 3 & 2 & & 1 & Tin-glazed with white paste \\
\hline & 4 & 1 & & & \\
\hline & 5 & 6 & & & \\
\hline & 6 & 4 & & & \\
\hline & 7 & 1 & & & \\
\hline & 8 & 5 & & & \\
\hline \multirow[t]{5}{*}{ ST 3} & 4 & & 1 & & \\
\hline & 5 & 2 & 3 & & \\
\hline & 6 & 1 & & & \\
\hline & 7 & 1 & & & \\
\hline & 8 & 6 & 1 & 1 & Tin-glazed with red paste \\
\hline $\begin{array}{ll}\text { ST } 4 \\
\end{array}$ & 3 & 1 & & & \\
\hline ST 11 & 2 & 1 & & & \\
\hline ST 24 & 8 & 1 & & & \\
\hline \multicolumn{2}{|c|}{ Totals } & 67 & 5 & 4 & \\
\hline
\end{tabular}




\section{Glass}

Clear, brown, green, and aqua vessel glass, and clear flat glass fragments were recovered from STs 1,3 , and 9 . The brown bottle glass from ST 9 is modern. The remainder of the fragments are too small to date.

\section{Metal and Nails}

Various fragments of rusted metal were recovered from STs 1, 2, 3, and 8. These fragments were not identifiable. One cut nail was recovered from ST 2, Level 2. Three wire nails were recovered from ST 3, one each from Levels 3, 5, and 6 .

\section{Lithics}

Chert and quartzite artifacts $(n=78)$ were recovered from STs $1-5,7-9,13,17,18$, and 24. Lithic artifacts recovered include 68 chert flakes, three quartzite flakes, one large quartzite biface, one chert biface fragment, two chert utilized flakes, one complete chert uniface, one fragmented chert uniface, and one midsection of a Guerrero point (Table 2).

The quartzite biface represents an early reduction stage. It is thick and cortex is present on one face. The complete chert uniface is blocky in shape and has use wear on alternate sides of the adjacent working edges. Cortex is present on 39 percent $(n=28)$ of the recovered flakes, as well as the large biface and one utilized flake. Primary flakes were defined as those with 100 percent cortex covering the dorsal surface, secondary flakes have some cortex remaining, and tertiary flakes have no cortex. The percentage ratio of primary to secondary to tertiary flakes from this collection is 11 to 28 to 61 .

\section{Faunal Remains}

Animal bone was by far the most common artifact recovered during shovel testing. All animal bone was identified to the lowest possible taxonomic level using CAR's vertebrate comparative collection and standard reference guides (Gilbert 1990; Hillson 1986; Olsen 1968). For each specimen taxon, element, side, weight, and presence of burning were recorded. Butcher marks were also recorded and the type of mark, including knife and chop marks, was identified. Where possible, it was determined if the mark was made by a metal or stone tool. Spiral fractures indicative of breakage while the bone is green were also recorded. Such fractures result from marrow extraction, trampling, or carnivore gnawing (Lyman 1994).

The present sample consists of 1,327 pieces of bone weighing 1,599.03 grams (Table 3). More than 90 percent of the bone $(n=1,254)$ was recovered from STs $1-3$, primarily $(n=912)$ from ST 1 alone. By weight, 80 percent of the bone came from ST 1, 69 percent by count. Much of the bone is not identifiable to any taxonomic level due to fragmentation; average weight per specimen is less than 1.5 grams.

Table 2. Lithic Artifacts from Mission Espiritu Santo

\begin{tabular}{|c|c|l|c|c|c|c|l|}
\hline \hline Unit & Level & Tool Type & $\begin{array}{c}\text { Length } \\
(\mathrm{mm})\end{array}$ & $\begin{array}{c}\text { Width } \\
(\mathrm{mm})\end{array}$ & $\begin{array}{c}\text { Thickness } \\
(\mathrm{mm})\end{array}$ & $\begin{array}{c}\text { Weight } \\
(\mathrm{g})\end{array}$ & Notes \\
\hline \hline ST 1 & 5 & Guerrero point & 17.2 & 16.5 & 5.1 & 1.32 & Midsection, broken from use \\
\hline ST 1 & 4 & Biface & 84.8 & 53.7 & 37.3 & 160.86 & Quartzite biface in early stage of \\
\hline ST 2 & 3 & Biface & 20.4 & 15.0 & 3.9 & 1.05 & Fragment \\
\hline ST 7 & 2 & Uniface & 24.5 & 22.0 & 8.7 & 5.70 & Scraper, adjacent edges used on \\
\hline ST 1 & 6 & Uniface & 15.3 & 11.2 & 3.7 & 0.57 & Fragment \\
\hline ST 1 & 6 & Utilized Flake & 37.2 & 36.5 & 18.8 & 24.83 & Used as a scraper, cortex present \\
\hline ST 2 & 6 & Utilized Flake & 27.8 & 18.0 & 5.0 & 2.64 & \\
\hline
\end{tabular}


Table 3. Counts and Weights of Animal Bone

\begin{tabular}{|l|l|c|c|c|c|}
\hline \multirow{2}{*}{ Taxon Identified (ID) } & \multirow{2}{*}{ Common Name } & \multicolumn{2}{|c|}{ NISP } & Weight & \% W \\
\cline { 3 - 4 } & & $\#$ & $\%$ & $(\mathrm{~g})$ & Wgt \\
\hline Bos taurus and bovid & Cow/Bison & 51 & 76 & 451.68 & 98 \\
\hline Odocoileus virginianus & White-tail deer & 1 & 1.5 & 4.68 & 1 \\
\hline Artiodactyla & deer/sheep/goat & 1 & 1.5 & 0.41 & $<1$ \\
\hline Sylvilagus sp. & Cottontail rabbit & 2 & 3 & 0.48 & $<1$ \\
\hline Rodentia & Rodent & 1 & 1.5 & 0.02 & $<1$ \\
\hline Anser sp. & Goose & 1 & 1.5 & 0.58 & $<1$ \\
\hline Meleagris gallopavo & Turkey & 4 & 6 & 3.37 & $<1$ \\
\hline Trionyx sp. & Softshell turtle & 1 & 1.5 & 0.65 & $<1$ \\
\hline Testudinata & turtle & 5 & 7 & 1.24 & $<1$ \\
\hline \multicolumn{2}{|r|}{ Total Identified Bone } & 67 & 100 & 463.11 & 100 \\
\hline
\end{tabular}

\begin{tabular}{|l|c|c|c|c|}
\hline \multirow{2}{*}{ Unidentified (UID) Bone } & \multicolumn{2}{c|}{ Count } & Weight & $\begin{array}{c}\text { \% UID } \\
\text { Wgt }\end{array}$ \\
\cline { 2 - 4 } & $\#$ & $\%$ & (g) & \% \\
\hline large mammal & 209 & 17 & 594.13 & 52 \\
\hline medium mammal & 5 & $<1$ & 6.89 & $<1$ \\
\hline small mammal & 1 & $<1$ & 0.49 & $<1$ \\
\hline unidentified mammal & 1015 & 81 & 524.18 & 46 \\
\hline unidentified bird & 25 & 2 & 8.07 & $<1$ \\
\hline unidentified & 5 & $<1$ & 2.16 & $<1$ \\
\hline
\end{tabular}

In order to glean as much information as possible from the assemblage, the size of the animal the bone came from was noted whenever possible (for mammals only). A simple size category designation of large, medium, or small was used. The large mammal category includes cow, horse, and bison; the medium mammal category ranges from deer/goat/sheep to coyote size; and the small mammal category ranges from jackrabbit to rat size.

With a highly fragmented collection, the post-cranial distinction between cow and bison is difficult at best. Several metatarsal fragments and one complete tooth were positively identified as cow. The remaining identified bovid bone is also most likely cow; however, since some of it may be bison, it was simply designated "bovid" and combined for this discussion.

Identified taxa include bovid, white-tail deer, cottontail rabbit, rodent, goose, turkey, and softshell turtle. The most common species by far was bovid, making up 76 percent of the identified bone by count, and 98 percent by weight. All the identified bovid bone came from STs 1-3, and all but nine pieces of the 209 unidentified large mammal bone came from the same shovel tests. Knife marks were noted on seven specimens: two bovid and five unidentified mammal fragments. Chop marks were noted on 14 specimens: four bovid, five unidentified large mammal, and five unidentified mammal. One of the chop marks on an unidentified large mammal bone was determined to have been made with a stone tool.

Spiral fractures were noted on 89 specimens: four bovid, 51 unidentified large mammal, one medium unidentified mammal, and 33 unidentified mammal. The frequency of spiral fractures may give some indication of processing of bone before discard. It is difficult to determine whether the high degree of fragmentation is due to butchering and consumption practices or post-depositional disturbance. This 
problem is magnified due to the recent breaks resulting from excavation of the shovel tests. The extent of fragmentation is illustrated by looking at the minimum number of individuals needed (MNI) to account for the bone. MNI was calculated using matched-pairs method from White (1953:397). The bovid and large mammal bone could have come from the butchering of just two animals.

\section{Mussel Shell}

Mussel shell was recovered from eight of the shovel tests, most of which where located within the camping area. Though the shell was collected from shovel tests, it is most likely a natural occurrence and not cultural given that most of the shell was recovered from the lower terrace in association with very few other artifacts.

\section{Discussion and Recommendations}

A surprisingly large number of artifacts was recovered from very few shovel tests during this investigation. The presence of Spanish colonial ceramics, stone tools, and a large quantity of animal bone, along with a lack of more-recent refined ceramics, all within the same context indicate that intact mission-period archaeological deposits are present in the area to the east of the mission compound wall. The high concentration of Spanish colonial artifacts recovered from the first three shovel tests may indicate the presence of a midden or refuse area just outside the wall. However, some disturbance in this area is indicated by the presence of round nails in ST 3.

The analysis of the Spanish colonial period artifacts recovered was undertaken to make comparisons with other Spanish missions along the San Antonio River valley. Sample size did not allow for much more than gross comparisons, but some general patterns did occur. The stone tool and debitage assemblage appears to represent late-stage reduction activities. The relative abundance of faunal material recovered from just a few shovel tests indicates the possibility of extensive future research into subsistence at the mission. It is not surprising that most of the identified bone is bovid, given that cattle ranching was the main income for the mission during its peak. The fragmentary condition of the bone prohibits much in the way of identification and analysis, but may represent extensive processing of bone or postdepositional activities. Unfortunately a good portion of the breakage seen in this collection was the result of excavation in constrained shovel tests. Plans for future excavations should take into account the need for larger test units in areas with a high density of faunal material.

If the new line is placed within the existing pipeline trench (in the area of STs 1-5, Figure 2), further testing is not required. If the new line cannot be placed in the old trench, it is recommended that further archaeological investigations be conducted along the proposed trench line between the park entrance road and the beginning of the water line replacement near the mission.

Modern artifacts from the shovel tests 6-9 indicate the area just east of the entrance road is disturbed, most probably during construction of the park residence and driveway there. Although two Goliad ceramic sherds and five chert flakes were recovered from STs 10-32, each was recovered from separate tests holes and from various levels within the shovel tests. Given this low density and scattered distribution these artifacts do not appear to represent an intact site. Therefore, excavation along the proposed trench line within the camping area will not impact intact cultural remains. However, if trenching varies from the marked line tested during this investigations, further testing or monitoring should be conducted by an archaeologist to insure no intact cultural deposits are disturbed. 


\section{References Cited}

Blair, W. F.

1950 The Biotic Provinces of Texas. Texas Journal of Science 2(1):93-117.

Bolton, H. E.

1970[1915] Texas in the Middle Eighteenth Century. University of Texas Press, Austin.

Castañeda, C. E.

1938 The Mission Era, The Missions at Work 1731-1761. Our Catholic Heritage in Texas Vol. III. Von Boeckmann-Jones, Austin.

Freidrichs, I. H.

1967 History of Goliad. Regal, Victoria, Texas.

Gilbert, B. M.

1990 Mammalian Osteology. Missouri Archaeological Society, Columbia.

Godfrey, C. L., G. S. McKee, and H. Oakes

1973 General Soil Types of Texas. Soil Conservation Service, United States Department of Agriculture, Washington, D. C.

Hard, R. J., A. A. Fox, I. W. Cox, K. J. Gross, B. A. Meissner, G. I. Méndez, C. L. Tennis, and J. E. Zapata 1995 Excavations at Mission San José y San Miguel de Aguayo, San Antonio, Texas. Archaeological Survey Report, No. 218. Center for Archaeological Research, The University of Texas at San Antonio.

Hillson, S.

1986 Teeth. Cambridge University Press, Cambridge.

Ivey, J. E., and A. A. Fox

1982 Archaeological Investigations at Mission Concepción and Mission Parkway. Archaeological Survey Report, No. 114. Manuscript on file. Center for Archaeological Research, The University of Texas at San Antonio.

Lyman, R. L.

1994 Vertebrate Taphonomy. Cambridge University Press, Cambridge.

Mounger, M. A.

1959 Mission Espiritu Santo of Coastal Texas: An Example of Historic Site Archeology. Unpublished Master's thesis, The University of Texas at Austin.

O'Connor, K. S.

1966 The Presidio La Bahía del Espíritu Santo de Zuñiga, 1791 to 1846. Von Boeckmann-Jones, Austin.

Olsen, S. J.

1968 Fish, Amphibian, and Reptile Remains from Archaeological Sites Part I: Southeastern and Southwestern United States. Peabody Museum, Cambridge 
Ramsdell, C.

1934 Spanish Goliad. Manuscript on file. The University of Texas Archives, Austin.

Roell, C. H.

1996 Aranama College. In The New Handbook of Texas, edited by R. Tyler, I:215. Texas State Historical Association, Austin.

White, T. E.

1953 A Method of Calculating the Dietary Percentages of Various Food Animals Utilized by Aboriginal Peoples. American Antiquity 18:396-398. 